\title{
PENGARUH PEMBERIAN PUPUK UREA DAN JARAK ELEKTRODA TERHADAP TEGANGAN LISTRIK PLANT MICROBIAL FUEL CELL TANAMAN PADI (ORYZA SATIVA)
}

\section{The Effect of Urea Fertilizer and Electrode Gaps Toward The Voltage of Plant Microbial Fuel Cell Based on Oryza Sativa}

\author{
Angky Wahyu Putranto ${ }^{1 *}$, Yusron Sugiarto ${ }^{1}$, Novalia Kusumarini ${ }^{2}$, Tiara Wiranti $^{1}$, Lisa Normalasari ${ }^{1}$ \\ ${ }^{1}$ Jurusan Teknologi Hasil Pertanian - Fakultas Teknologi Pertanian - Universitas Brawijaya \\ Jalan Veteran, Malang 65145 \\ ${ }^{2}$ Jurusan Tanah - Fakultas Pertanian - Universitas Brawijaya \\ Jalan Veteran, Malang 65145 \\ *Penulis Korespondensi: email: angkywahyu@gmail.com
}

\begin{abstract}
ABSTRAK
Plant Microbial Fuel Cell (PMFC) merupakan salah satu penghasil bioenergi berkelanjutan yang tidak mengganggu produksi pangan serta mereduksi energi input selama produksi energinya. Tanaman padi (Oryza sativa) merupakan tanaman yang berpotensi sebagai penghasil tegangan listrik dalam PMFC. Penelitian ini membahas tentang pengaruh variasi pemupukan dengan pupuk urea $(1,5$, dan $10 \mathrm{~g})$ dan jarak elektroda $(4,6$, dan $8 \mathrm{~cm})$ dalam sistem PMFC. Variabel yang diukur yaitu tegangan listrik maksimal yang dihasilkan tanaman padi, arus listrik maksimal dan daya listrik maksimal yang dihasilkan. Perekaman data keluaran tegangan listrik dilakukan pada semua sampel sistem PMFC selama 5 hari, mulai pukul 08.00 WIB hingga 15.00 WIB. Penelitian ini menunjukkan bahwa nilai tegangan listrik maksimum diperoleh perlakuan pemberian pupuk urea $10 \mathrm{~g}$ dan jarak elektroda $6 \mathrm{~cm}$ dengan nilai tegangan listrik maksimal sebesar $196 \mathrm{mV}$, arus listrik maksimal $0.78 \mathrm{~mA}$ dan daya listrik maksimal sebesar $153.66 \mathrm{~mW} / \mathrm{cm}^{2}$

Kata kunci : Jarak Elektroda, Padi, PMFC, Tegangan Listrik, Urea

ABSTRACT

Plant Microbial Fuel Cell (PMFC), one of sustainable bioenergy sources which is not interfere with food production and could reducing energy input during energy production. Oryza sativa is a plant that has potential as a source of electrical voltage in PMFC. This study explained the influence of urea fertilization variation $(1,5$, and $10 \mathrm{~g})$ and electrode gaps $(4,6$, and $8 \mathrm{~cm})$ in PMFC system. Variables measured are the maximum voltage produced by rice plants, maximum electric current and maximum power density. The output electrical voltage data was recorded on all samples PMFC system for 5 days, from 08.00 am until $03.00 \mathrm{pm}$. Based on this study, the maximum voltage obtained on $10 \mathrm{~g}$ of urea fertilizer and the electrode gap of $6 \mathrm{~cm}$ with maximum electric voltage of $196 \mathrm{mV}$, maximum electric current of $0.78 \mathrm{~mA}$ and maximum power density of $153.66 \mathrm{~mW} / \mathrm{cm}^{2}$
\end{abstract}

Keywords : Electrode Gaps, PMFC, Paddy, Urea, Voltage 


\section{PENDAHULUAN}

Pengembangan energi alternatif yang berkelanjutan dan ramah lingkungan saat ini dilakukan untuk mengatasi keterbatasan energi fosil. Bioetanol dan biodiesel merupakan salah satu energi alternatif dari biomassa tumbuhan masih memiliki beberapa permasalahan. Hal ini terkait dengan berkurangnya produksi pangan serta dibutuhkan energi input yang cukup besar dalam penyediaan biomassa dan proses produksi bioenergi (Lu et al., 2015). Oleh karena itu dilakukan penelitian energi alternatif lain yang tidak mengancam ketahanan pangan dan bersifat sustainable.

Plant Microbial Fuel Cell atau PMFC merupakan pengembangan dari Microbial Fuel Cell (MFC) untuk memproduksi bioenergi tanpa mengganggu produksi pangan serta mereduksi energi input selama produksi energi. Perbedaan yang mendasar dalam PMFC adalah elektron dihasilkan dari aktivitas mikroorganisme tanah yang ditumbuhi tanaman (De Schlampaire et al., 2008; Kaku et al., 2008; Strik et al., 2008). Penelitian PMFC dengan menggunakan tanaman tinggi telah banyak dilakukan seperti pada Glyceria maxima (Strik et al., 2008), Spartina anglica (Timmers et al., 2010) dan dapat menghasilkan energi listrik secara berkelanjutan. Menurut De Schamphelaire et al. (2008), PMFC dapat diimplementasikan pada tanaman padi sehingga pada budidaya padi di sawah tidak hanya memproduksi gabah namun juga dapat memproduksi energi listrik. Penelitian sebelumnya menunjukkan potensi produksi energi listrik pada PMFC berbasis tanaman padi (Oryza sativa) hingga $6 \mathrm{~mW} / \mathrm{m}^{2}$ (Kaku et al., 2008).

Berdasarkan data Badan Pusat Statistik (2015), luas sawah yang ditumbuhi padi di Indonesia mencapai 26458 ha di tahun 2014. Hal tersebut menjadikan Indonesia sebagai negara agraris yang sangat berpotensial untuk pengembangan PMFC. Sawah merupakan lahan yang sengaja digenangi air untuk budidaya padi. Lahan sawah yang tergenang akan menyebabkan kondisi anaerob pada tanah yang menyebabkan hidupnya bakteri anaerob seperti bakteri pengurai sulfat bakteri pengurai besi bakteri fermentasi dan bakteri metana (Moqsud et al., 2015).

Salah satu faktor yang mempengaruhi tegangan listrik PMFC adalah pemberian pupuk. Penggunaan pupuk kimia serta pen- golahan tanah merupakan faktor penting berkaitan dengan kesuburan tanah. Tetapi, dosis pupuk yang berlebihan menyebabkan kandungan bahan organik tertentu dalam tanah terus berkurang dan berakibat pada kualitas tanah serta pertumbuhan tanaman. Selain pemupukan, faktor penting lainnya adalah jarak elektroda yang menentukan besarnya output listrik PMFC. Berdasarkan Helder et al. (2012) faktor jarak anoda dan katoda menentukan besarnya resistansi internal pada sistem PMFC. Pada penelitian Strik et al., (2008) dan Timmers et al., (2010), yang menggunakan desain turbular dengan penempatan anoda diatas dan katoda di bawah membran, menunjukkan bahwa jarak transportasi elektron dari anoda ke katoda yang relatif panjang akan menyebabkan penurunan terhadap output listrik yang dihasilkan.

Oleh karena itu, pada penelitian ini akan dibahas mengenai variasi pemberian dosis pemupukan dan jarak elektroda terhadap output listrik yang dihasilkan PMFC berbasis tanaman padi (Oryza sativa). Tujuan penelitian ini adalah mengetahui pengaruh dosis pemupukan pupuk anorganik urea dan jarak elektroda terhadap tegangan, arus dan daya listrik PMFC tanaman padi. Diharapkan hasil dari penelitian PMFC berbasis tanaman padi ini dapat dijadikan langkah awal untuk pengembangan alternatif energi listrik di Indonesia yang ramah lingkungan dan tidak mengganggu produktivitas tanaman pangan.

\section{BAHAN DAN METODE}

\section{Bahan}

Tanah yang digunakan dalam penelitian memiliki karakteristik berliat (kandungan bahan organik sebesar $2.9 \%$ dan $\mathrm{pH}$ 5.7) yang didapatkan dari areal persawahan kecamatan Karangploso, Malang. Tanaman padi menggunakan varietas IR64 yang berumur 20-30 hari, dan pupuk urea yang digunakan didapatkan dari BPPT Jawa Timur dengan kandungan nitrogen sebesar $46 \%$

\footnotetext{
Alat

Alat yang digunakan adalah gerinda potong, bor duduk, baterai, resistor, kabel, data logger Graphtec GL220, AVO meter
} 
Sanwa CD800A, gelas ukur, dan pot. Bahan yang digunakan dalam penelitian adalah elektroda karbon dengan ukuran $\mathrm{p} \times 1 \times \mathrm{t}=5 \mathrm{x}$ $5 \times 1 \mathrm{~cm}$

\section{Metode}

Pada penelitian ini disiapkan media tanam padi dan media tumbuh mikroorganisme yang diletakkan ke dalam pot beserta tanaman padi. Setelah itu kedua elektroda karbon (anoda dan katoda) dimasukkan ke dalam pot (diameter $=20 \mathrm{~cm}$; tinggi $=23$ $\mathrm{cm})$ dan ditutup dengan tanah. Anoda diletakkan secara horizontal di dasar pot $(3 \mathrm{~cm}$ dari dasar pot), sementara katoda diletakkan secara vertikal pada bagian samping dalam pot yang kemudian diatur jaraknya dengan anoda sesuai variabel penelitian 4, 6, dan 8 $\mathrm{cm}$. Ilustrasi skema rangkaian pemasangan elektroda dan pengukuran variabel menggunakan data logger ditunjukkan pada Gambar 1. Masing-masing ujung elektroda kemudian dihubungkan dengan kabel yang akan disambungkan ke data logger untuk mengetahui tegangan listrik (volt) yang dihasilkan. Kabel dari salah satu elektroda dihubungkan dengan resistor $10 \mathrm{ohm}$ untuk diketahui nilai arus listrik berdasarkan perhitungan pada hukum ohm. Arus listrik yang dihasilkan pada PMFC adalah current density yang didapat dengan Persamaan 1 (Moqsud et al., 2015).

$\mathrm{I}=\mathrm{V} / \mathrm{a} \cdot \mathrm{R}$

Dengan I adalah arus listrik (mA), V adalah tegangan listrik $(\mathrm{mV}), \mathrm{R}$ adalah hambatan (ohm), serta a merupakan luas penampang elektroda yang digunakan pada instalasi PMFC. Pada penelitian ini elektroda karbon yang digunakan memiliki luas penampang $25 \mathrm{~cm}^{2}$. Pada daya listrik $(\mathrm{mW})$ dihitung berdasarkan Persamaan 2.

$\mathrm{P}=\mathrm{V} \times \mathrm{I}$

Proses perekaman data keluaran PMFC dilakukan selama 5 hari mulai dari jam 08.00 - 15.00 WIB. Tegangan listrik yang dihasilkan akan direkam oleh data logger setiap 10 menit. Tegangan dan daya listrik yang dihasilkan PMFC tanaman padi selama 5 hari kemudian dicari nilai tegangan, arus dan daya yang maksimum (V peak, I peak dan $\mathrm{P}$ peak) dari masing-masing variasi perlakuan untuk kemudian dihitung arus dan daya maksimal yang dihasilkan.

\section{Rancangan Penelitian}

Rancangan penelitian terdiri atas 2 faktor yaitu pupuk urea yang diberikan serta jarak anoda dan katoda terhadap sistem PMFC berbasis tanaman padi. Faktor pertama yaitu dosis pemberian pupuk urea $(1$, 5 , dan 10 gram) dan faktor kedua (jarak elektroda) terdiri 3 level $(4,6$, dan $8 \mathrm{~cm})$, sehingga diperoleh 9 kombinasi perlakuan. Data yang diperoleh dianalisis dengan menggunakan analisis ragam satu arah (Oneway Analysis of Variance $=$ Oneway ANOVA) dengan metode RAL secara faktorial. Apabila terdapat beda nyata pada analisis ragam (ANOVA), maka dilakukan uji Beda Nyata Terkecil (BNT) dengan taraf nyata $5 \%$.

\section{HASIL DAN PEMBAHASAN}

\section{Pengaruh Pemberian Pupuk Urea Terhadap Tegangan Listrik}

Hasil tegangan listrik yang dihasilkan PMFC tanaman padi dengan variasi perlakuan jarak elektroda pada variasi pemberian pupuk urea secara umum dapat dilihat pada Gambar 2. Pada ketiga grafik tersebut menunjukkan kecenderungan peningkatan tegangan listrik yang dihasilkan oleh PMFC tanaman padi hari pertama sampai hari ke lima dengan adanya pengaruh pemberian pupuk urea. Akan tetapi, perlakuan pemberian pupuk urea pada tegangan listrik yang dihasilkan dari PMFC tanaman padi juga tidak menunjukkan adanya pengaruh yang signifikan yang dibuktikan dengan nilai F hitung lebih rendah dari $\mathrm{F}$ tabel pada taraf $5 \%$ $(0.76<4.26)$.

Berdasarkan grafik pada Gambar 2A, 2B, dan 2C, PMFC tanaman padi telah menghasilkan tegangan listrik sejak hari pertama dan kontinyu hingga hari ke-5. Secara umum pemberian pupuk urea menentukan kondisi awal tegangan listrik PMFC yang dihasilkan. Hal ini terlihat pada kenaikan tegangan listrik yang dihasilkan pada hari pertama untuk setiap perlakuan pemberian dosis pupuk. Pada perlakuan jarak elektroda $8 \mathrm{~cm}$ dengan pemberian urea $1 \mathrm{~g}, 5 \mathrm{~g}$, dan $10 \mathrm{~g}$ masingmasing sebesar $72.55 \mathrm{mV}, 82.75 \mathrm{mV}$, dan $96.75 \mathrm{mV}$. Hal ini sesuai dengan pendapat Mosqud et al., (2015), bahwa dengan penam- 
Jurnal Teknologi Pertanian Vol. 19 No. 1 [April 2018] 43-50

Pengaruh Pemberian Pupuk Urea dan Jarak Elektroda Terhadap Tegangan Listrik [Putranto dkk]

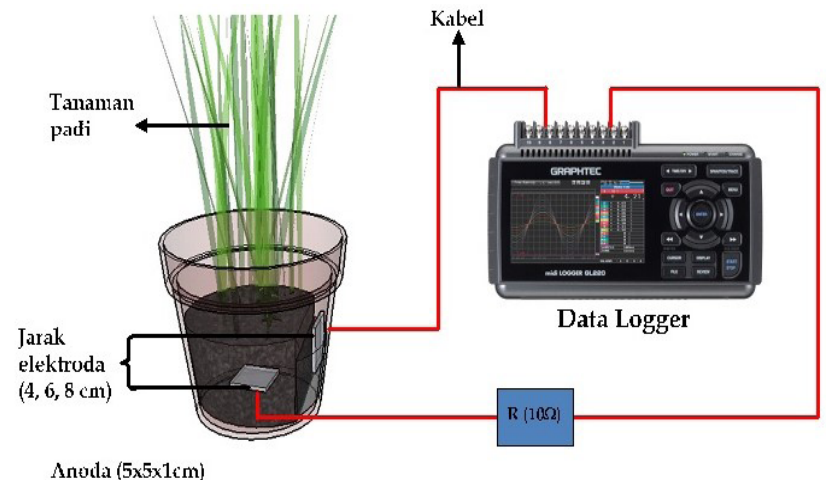

Gambar 1. Skema rangkaian PMFC padi

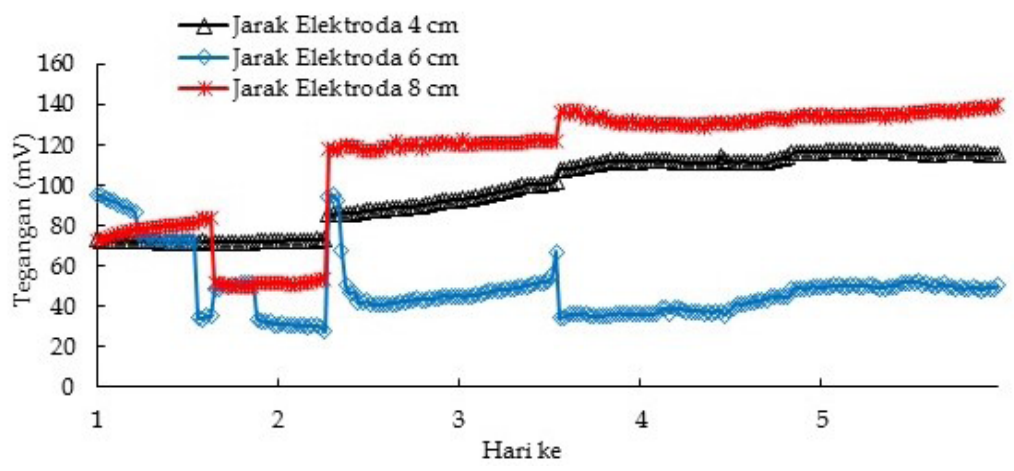

(a)

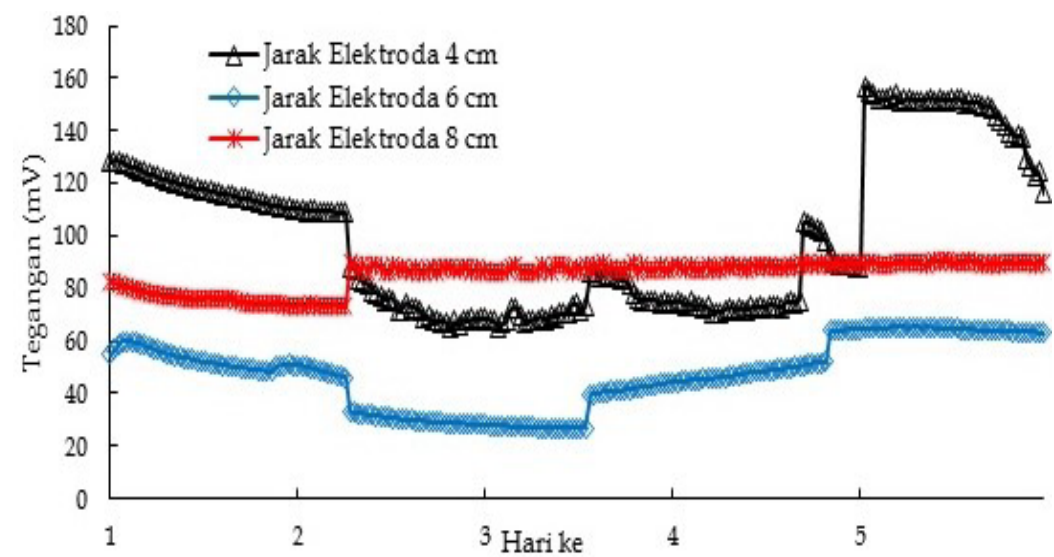

(b)

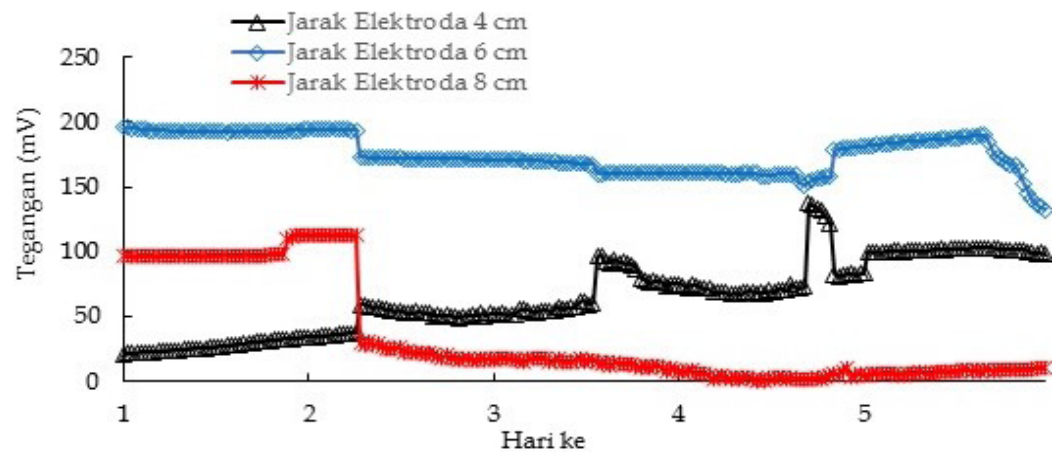

(c)

Gambar 2. Tegangan listrik yang dihasilkan pada variasi perlakuan jarak elektroda selama 5 hari.

(a) $1 \mathrm{~g}$ urea; (b) $5 \mathrm{~g}$ urea; dan (c) $10 \mathrm{~g}$ urea 
bahan pupuk kompos pada PMFC tanaman padi, maka akan meningkatkan tegangan listrik mencapai $700 \mathrm{mV}$ dibanding dengan tanaman padi tanpa pemberian pupuk yang hanya mencapai tegangan listrik maksimal $390 \mathrm{mV}$.

Namun demikian, setelah 5 hari pengamatan, banyaknya urea yang diberikan tidak meningkatkan tegangan listrik secara signifikan sampai pada hari ke-5. Hal ini terjadi pada pemberian urea 1 dan $5 \mathrm{~g}$, dimana penurunan tegangan terjadi pada jarak elektroda $6 \mathrm{~cm}$ (Gambar 2A dan Gambar 2B) yaitu masing-masing 27, 9, dan $26.75 \mathrm{mV}$. Hal tersebut juga terjadi pada pemberian urea $10 \mathrm{~g}$ dan jarak elektroda $8 \mathrm{~cm}$ (Gambar 2C), dimana juga terjadi penurunan tegangan listrik yang sangat signifikan mencapai $0.7 \mathrm{mV}$ dan terus menurun pada hari ke-5. Hal ini dikarenakan semakin banyaknya urea yang ditambahkan akan menyebabkan bahan organik di dalam tanah menjadi berkurang. Bahan organik tanah yang semakin berkurang akan menurunkan jumlah bakteri penghasil tegangan pada sistem microbial fuel cell (MFC). Rhizodeposits yang dikeluarkan oleh akar tanaman padi tidak bisa diserap secara maksimal oleh mikroba di dalam tanah jika ketersediaan mikroba tersebut semakin menipis. Rhizodeposits yang umumnya dalam bentuk karbohidrat nantinya akan dirubah oleh mikroorganisme di dalam tanah menjadi tegangan listrik. Jumlah rhizodeposits yang menurun mengakibatkan tegangan yang dihasilkan juga menurun. Hal ini juga terjadi pada penelitian Mosqud et al., (2015), bahwa terjadi penurunan tegangan listrik pada penambahan pupuk dari $40 \mathrm{~g}$ menjadi 120 $\mathrm{g}$ di dalam pot kapasitas $17.232 \mathrm{~cm}^{3}$. Jumlah pupuk yang cukup banyak di dalam pot dengan kapasitas $1200 \mathrm{~cm}^{3}$ akan membuat tanah menjadi panas dan lebih banyak menyerap air. Berdasarkan Amir et al. (2012) menambahkan bahwa penggunaan pupuk kimiawi dalam jangka waktu lama dan dalam jumlah yang cukup banyak dapat menyebabkan degradasi tanah dan pencemaran lingkungan.

Hal ini berbeda dengan pemberian pupuk organik, karena penambahan pupuk organik yang dilakukan tidak hanya menambah nutrisi pada tanah untuk pertumbuhan tanaman padi, namun juga sebagai makanan tambahan (bahan organik) untuk tumbuh dan hidup di dalam tanah. Oleh karena itu disarankan untuk menggunakan pupuk organik atau kompos pada PMFC tanaman padi. Hal ini dikarenakan pupuk organik lebih ramah lingkungan sebab tidak merusak struktur akar maupun tanah. Selain itu, pupuk organik dapat meningkatkan mikroba dalam tanah yang dapat membantu dalam meningkatkan suplai C organik dalam komunitas mikroba dalam tanah (Lazcano et al., 2013).

\section{Pengaruh Jarak Elektroda terhadap Tegangan Listrik}

Tegangan listrik yang didapatkan dari masing-masing perlakuan pada hari ke-1 hingga hari ke 5 kemudian dicari tegangan maksimum (peak voltage) untuk masing-masing perlakuan seperti yang ditunjukkan pada Gambar 3.

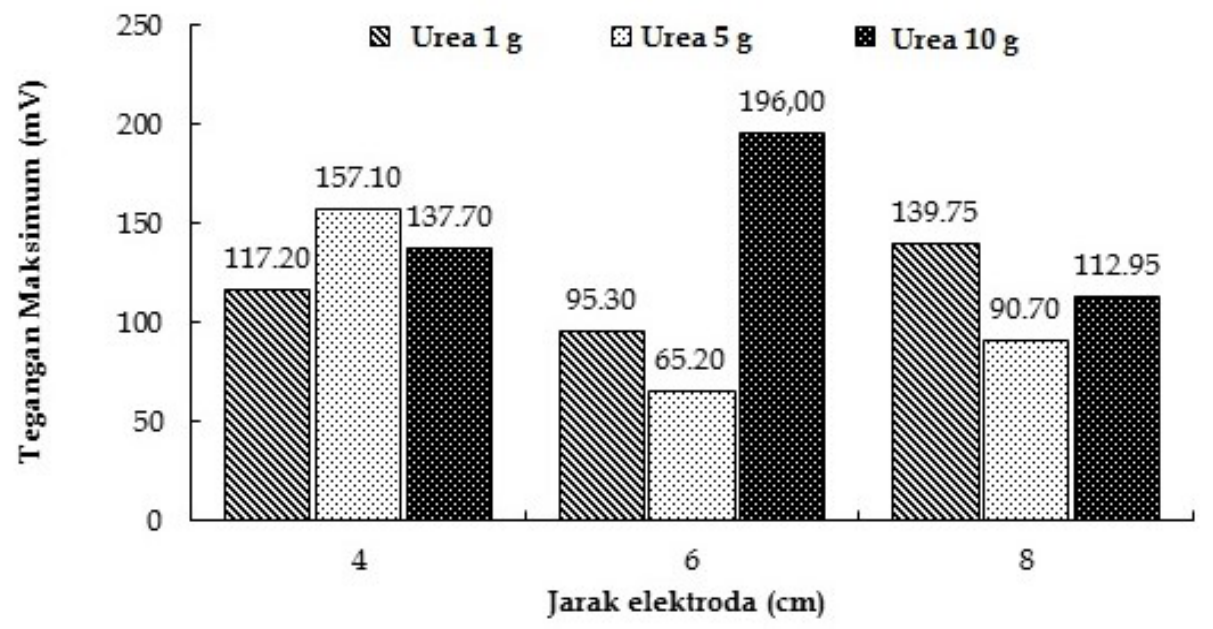

Gambar 3. Tegangan listrik maksimum yang dihasilkan masing-masing perlakuan 
Berdasarkan Gambar 3, tegangan maksimum yang dihasilkan terhadap kombinasi pupuk urea dan jarak elektroda berkisar antara 65.20-196 mV. Tegangan paling maksimum terdapat pada perlakuan pemberian pupuk urea $10 \mathrm{~g}$ dan jarak elektroda 6 $\mathrm{cm}$. Berdasarkan penelitian yang dilakukan Sajana et al. (2013), sistem microbial fuel cell yang dioperasikan pada jarak elektroda yang semakin besar dapat menghasilkan tegangan listrik yang lebih tinggi dibandingkan dengan microbial fuel cell dengan jarak elektroda yang lebih kecil. Namun pada penelitian ini semakin besar jarak elektroda yang diberikan tidak selalu memberikan hasil tegangan listrik yang maksimal.

Hal ini dapat disebabkan karena jarak elektroda yang berjauhan memperbesar daerah interaksi mikroba tanah dalam rizosfer yang melakukan proses metabolisme hasil fotosintesis tanaman sehingga semakin sedikit elektron yang dapat ditangkap oleh anoda. Akar tanaman menghasilkan berbagai jenis senyawa organik ke dalam tanah, yang mengandung eksudat yang berupa gula, asam organik, dan lainnya; hasil sekresi berupa polimer-polimer karbohidrat dan enzim; lisat berupa material berupa sel mati; serta gas berupa etilen dan $\mathrm{CO}_{2}$ (Uren et al., 2000; Bais et al., 2006). Semua material yang dilepas tersebut merupakan proses rizodeposisi tanaman dan produknya disebut dengan rizodeposit yang kemudian digunakan dalam proses produksi energi listrik pada PMFC oleh mikroba tanah dalam rizosfer (Bais et al., 2006). Jarak yang jauh dari anoda ke katoda mengarah ke dalam transport losses (kehilangan) di anoda. Ketika elektron diproduksi diantara kompartemen anoda dan katoda pada jarak yang cukup jauh, transportasi untuk perjalanan proton dari anoda melalui membran ke katoda relatif panjang (Helder et al., 2012).

Selain itu, hasil pada Gambar 3 juga dilakukan analisis secara ANOVA satu arah untuk mengetahui adanya pengaruh atau tidak pada perlakuan yang telah dilakukan pada penelitian ini. Perlakuan secara umum yaitu penambahan pupuk urea serta perubahan jarak elektroda tidak memberikan pengaruh yang signifikan terhadap tegangan listrik yang dihasilkan yang dibuktikan dengan nilai $\mathrm{F}$ hitung lebih rendah dari $\mathrm{F}$ tabel pada taraf $5 \%(3.20<3.23)$. Begitu pula pada perlakuan perubahan jarak elektroda juga tidak memberikan pengaruh yang signifikan terhadap tegangan listrik yang dihasilkan karena nilai $\mathrm{F}$ hitung lebih rendah dari $\mathrm{F}$ tabel pada taraf $5 \%(1.51<4.26)$. Namun pada perlakuan yang dilakukan dalam penelitian ini terdapat pengaruh nilai tegangan listrik yang dihasilkan PMFC tanaman padi oleh interaksi pemberian pupuk urea dan jarak elektroda. Hal ini dibuktikan dengan nilai $\mathrm{F}$ hitung yang lebih tinggi dari $\mathrm{F}$ tabel $5 \%(5.26>3.63)$.

Nilai tegangan listrik maksimum (peak voltage) yang dihasilkan pada penelitian ini (196 mV) lebih rendah jika dibanding dengan penelitian yang dilakukan oleh Mosqud et al. (2015), dimana tegangan listrik tertinggi sebesar $700 \mathrm{mV}$ dihasilkan pada perlakuan dengan pemberian pupuk kompos $40 \mathrm{~g}$ dan jarak elektroda $5 \mathrm{~cm}$. Selain komposisi tanah dan pemberian pupuk yang berbeda, luas permukaan elektroda yang digunakan juga berbeda. Pada penelitian ini digunakan elektroda dengan luas permukaan $25 \mathrm{~cm}^{2}$ dan volume tanah yang digunakan adalah 1200 $\mathrm{cm}^{3}$. Pada penelitian yang dilakukan Moqsud et al. (2015), elektroda karbon yang digunakan adalah dalam bentuk serat (fiber carbon) dengan luas permukaan $125 \mathrm{~cm}^{2}$ dan densitas $1.75 \mathrm{~g} / \mathrm{cm}^{3}$ dengan volume tanah yang digunakan $17.232 \mathrm{~cm}^{3}$. Pada penelitian menggunakan MFC, semakin besar luas permukaan elektroda maka semakin besar pula beda potensial yang dihasilkan (Sinaga et al., 2014).

\section{Arus dan Daya Listrik PMFC Tanaman Padi}

Nilai arus listrik (mA) dan daya listrik $\left(\mathrm{mW} / \mathrm{cm}^{2}\right)$ dihitung berdasarkan Persamaan 1 dan 2. Arus listrik maksimal dan daya listrik maksimal yang dihasilkan oleh tanaman padi akibat perlakuan pemberian pupuk urea dan jarak elektroda dapat dilihat pada Tabel 2.

Berdasarkan Tabel 2, arus dan tegangan listrik maksimal yang dihasilkan oleh PMFC tanaman padi diperoleh pada perlakuan pemberian pupuk urea $10 \mathrm{~g}$ dan jarak elektroda $6 \mathrm{~cm}$ yaitu dengan arus listrik maksimal sebesar $0.78 \mathrm{~mA}$ dan daya listrik (power density) maksimal sebesar $153.66 \mathrm{~mW} / \mathrm{cm}^{2}$. Semakin meningkatnya arus listrik yang dihasilkan dari PMFC tanaman padi juga akan meningkatkan daya listrik. Hal ini dikarenakan berdasarkan Persamaan 2, yaitu besarnya daya listrik sebanding dengan arus listrik yang dihasilkan. Berdasarkan Tabel 2, juga dapat dilihat bahwa tegangan, arus dan daya listrik maksimal terdapat pada pemberian pupuk urea $10 \mathrm{~g}$, sehingga pemberian 
dosis pupuk tertinggi pada penelitian ini (10 g) menghasilkan daya listrik yang maksimal dibandingkan dengan pemberian dosis pupuk $1 \mathrm{~g}$. Namun pada penelitian ini tidak dilakukan pengukuran pertumbuhan tanaman padi dan beras yang dihasilkan akibat pemberian dosis pupuk yang dilakukan, sehingga korelasi antara pertumbuhan tanaman dan daya listrik yang dihasilkan terhadap dosis pemberian pupuk belum dapat dijelaskan pada penelitian ini. Akan tetapi, berdasarkan penelitian Moqsud et al., (2015), pemberian pupuk kompos akan menyebabkan tinggi tanaman padi semakin meningkat mencapai $100 \mathrm{~cm}$ pada minggu ke-14 dan daya listrik meningkat 3 kali lipat jika dibandingkan dengan tanpa pemberian pupuk kompos. Hal ini menunjukkan adanya korelasi positif antara daya listrik yang dihasilkan dengan pertumbuhan tanaman terhadap pemberian pupuk kompos.

Penelitian selanjutnya diharapkan dapat memberikan perbandingan antara pertumbuhan tanaman dan daya listrik maksimal yang dihasilkan terhadap berbagai variabel-variabel yang berpengaruh, sehingga akan dapat membuktikan bahwa tanah areal persawahan yang menerapkan teknologi PMFC akan menghasilkan tingkat pertumbuhan padi yang lebih baik dibandingkan dengan tanpa menerapkan teknologi PMFC. Oleh karena itu, teknologi PMFC tanaman padi ini sangat potensial untuk dikembangkan dan diterapkan di Indonesia untuk menghasilkan energi ramah lingkungan yang bersifat kontinyu dan tanpa mengganggu ketahanan pangan.

\section{SIMPULAN}

PMFC tanaman padi yang diberi perlakuan pupuk urea dan jarak elektroda pada penelitian ini telah mampu menghasilkan tegangan listrik. Nilai tegangan listrik maksimum dihasilkan oleh perlakuan pemberian pupuk urea $10 \mathrm{~g}$ dan jarak elektroda 6 $\mathrm{cm}$ dengan nilai tegangan listrik sebesar 196 $\mathrm{mV}$, arus maksimum $0.78 \mathrm{~mA}$ dan daya listrik maksimum sebesar $153.66 \mathrm{~mW} / \mathrm{cm}^{2}$. Meskipun hasil daya listrik yang dihasilkan cukup rendah, namun PMFC berbasis tanaman padi dapat digunakan secara berkelanjutan untuk pembangkit listrik berbasis bioelectricity yang ramah lingkungan, tidak menggangu produktivitas pangan dan cocok dikembangkan baik di negara maju maupun negara berkembang seperti di Indonesia.

\section{UCAPAN TERIMA KASIH}

Terima kasih disampaikan kepada Fakultas Teknologi Pertanian Universitas Brawijaya atas pembiayaan dana BOPTN dan segala fasilitas yang telah diberikan.

\section{DAFTAR PUSTAKA}

Amir, L, Sari, A, P, Hiola, F, Jumadi, O. 2012. Ketersediaan nitrogen tanah dan pertumbuhan tanaman bayam (Amaranthus tricolor L.) yang diperlakukan dengan pemberian pupuk kompos azolla. Sainsmat. 1(2):167-180

Badan Pusat Statistik. 2015. Luas lahan sawah menurutprovinsi(ha),2003-2015. Dilihat 25 November 2017. <https:/ / www.bps. go.id/dynamictable/2015/09/10/895/ luas-lahan-sawah-menurut-provinsiha-2003-2015.html>

Bais, H, P, Weir, T, L, Perry, L, G, Gilroy, S, Vivanco, J, M. 2006. The role of root exudates in Rhizosphere interactions with plants and other organisms. Annu. Rev. Plant. Biol. 57:233-266

De Schamphelaire, L, den Bossche, L, V, Dang, H, S, Hofte, M, Boon, N, Rabaey, K, Verstraete, W. 2008. Microbial fuel cells generating electricity from Rizodeposits of rice plants. Environ. Sci. Technol. 42(8): 3053-3058

Helder, M, Strik, D, Hamelers, H, V, M, Buisman, C, J, N. 2012. The flat-plate plant microbial fuel cell: the effect of new design on internal resistances. Biotechnolgy for Biofuels. 5:70

Kaku, N, Yonezawa, N, Kodama, Y, Watanabe, K. 2008. Plant/microbe cooperation for electricity generation in a rice paddy field. Appl. Microbiol. Biotechnol. 79(1):43-49

Lazcano, C, Brandón, M, G, Revilla, P, Domínguez, J. 2013. Short-term effects of organic and inorganic fertilizers on soil microbial community structure and function. Biology and Fertility of Solis. $49(6): 722-723$ 
Jurnal Teknologi Pertanian Vol. 19 No. 1 [April 2018] 43-50

Pengaruh Pemberian Pupuk Urea dan Jarak Elektroda Terhadap Tegangan Listrik [Putranto dkk]

Lu, L, Xing, D, Ren, Z, J. 2015. Microbial community structure accompanied with electricity production in a constructed wetland plant microbial fuel cell. Bioresource Technology. 195(11):115-121

Moqsud, M, A, Yoshitake, J, Bushra, Q, S, Hyodo, M, Omine, K, Strik, D. 2015. Compost in plant microbial fuel cell for bioelectricity generation. Waste. Manag. 36:63-69

Sajana, T, K, Ghangrekar, M, M, Mitra, A. 2013. Application of sediment microbial fuel cell for in situ reclamation of aquaculture pond water quality. Aquacultural Engineering. 57: 101-107

Sinaga, D, H, Suyati, L, Aminin, A, L, N. 2014. Studi pendahuluan pemanfaatan whey tahu sebagai substrat dan efek luas permukaan elektroda dalam sistem microbial fuel cell. Jurnal Sains $\mathcal{E}$ Matematika. 22(2):30-35
Strik, D, P, B, T, B, Hamelers, H, V, M, Snel, J, F, H, Buisman, C, J, N. 2008. Green electricity production with living plants and bacteria in a fuel cell. International Journal of Energy Research. 32(9): 870-876

Timmers, R, A, Strik, D, P, B, T, B, Hamelers, H, V, Buisman, C, J, N. 2010. Long term performance of a plant microbial fuel cell with Spartina anglica. Appl. Microbiol. Biotechnol. 86(3):973-981

Uren, NC, Pinton, E, Varanini, R, Naminipieri, Z. 2000. 'Types, Amounts, and Possible Functions of Compunds Released Into the Rhizosphere by Soil-Grown Plants'. Dalam S Willig, Z Varanini, P Nannipieri (eds.). The Rhizosphere Biochemistry and organic Substances at the Soil Plant Interface. CRC Press, USA 